\title{
High hepatitis B virus load is associated with hepatocellular carcinomas development in Chinese chronic hepatitis B patients: a case control study
}

\author{
Jin-Yong Zhou ${ }^{1,2}$, Le Zhang ${ }^{1,2}$, Lei Li', Guang-Yu Gu' ${ }^{1}$, Yi-Hua Zhou ${ }^{1,2}$ and Jun-Hao Chen ${ }^{\text {* }}$
}

\begin{abstract}
Background: Persistent hepatitis B virus (HBV) infection is a risk factor for hepatocellular carcinoma (HCC) development. This study aimed to clarify whether the high HBV DNA level is associated with HCC development by comparing HBV DNA levels between HBV infected patients with and without HCC.

Results: There were 78 male and 12 female patients in each group and there was no statistical difference between these two group patients' average ages. The HBV DNA level in the HCC patients was $4.73 \pm 1.71 \mathrm{Log}_{10} \mathrm{IU} / \mathrm{ml}$ while $3.90 \pm 2.01 \mathrm{Log}_{10} \mathrm{IU} / \mathrm{ml}$ in non-HCC patients $(P<0.01)$. The HBeAg positive rate was $42.2 \%$ (38/90) in the HCC group while $13.3 \%(12 / 90)$ in the non-HCC group $(P<0.001)$. Compared with patients with HBV DNA level of $<3$ $\log _{10} \mathrm{IU} / \mathrm{ml}$, the patients with level of 3 to $<4,4$ to $<5,5$ to $<6$, or $\geq 6 \log _{10} \mathrm{IU} / \mathrm{ml}$ had the odds ratio for HCC of 1.380 (95\% Cl, 0.544-3.499), 3.671 (95\% Cl, 1.363-9.886), 5.303 (95\% Cl, 1.847-15.277) or 3.030 (95\% Cl, 1.143-8.036), respectively.
\end{abstract}

Conclusions: HBV-related HCC patients had higher HBV DNA level than non-HCC counterparts. Our findings imply that active HBV replication is associated with the HCC development.

\section{Background}

Chronic hepatitis B virus (HBV) infection is a serious public health problem worldwide since more than 350 million people are chronic carriers [1-4]. Persistent HBV infection is a risk factor for the development of hepatocellular carcinoma (HCC). The viral factors, such as viral genotype and mutants, have been shown to be associated with the pathogenesis of HCC [5-7]. Recent studies show that HBV load may also be associated with the HCC development [8-15] because the HBV DNA level in HCC patients was higher than that in non-HCC patients [13-15]. However, other studies showed that the viral load in HBV-associated HCC patients was not higher than that in the patients without HCC [16,17].

HBV infection is still highly endemic in China although the prevalence of hepatitis B surface antigen

\footnotetext{
* Correspondence: nj_cjh@163.com

'Department of Laboratory Medicine, Nanjing Drum Tower Hospital, Nanjing University Medical School, Nanjing, China

Full list of author information is available at the end of the article
}

(HBsAg) has been reduced from $10 \%$ to $7.18 \%$ after the hepatitis $B$ vaccine has been widely used in infants $[18,19]$. The age-standardized incidence of HCC in China is 58 per 100000 persons for men and 22 per 100000 persons for women, which is high in the world [20]. However, the comparison of HBV DNA level between HCC and non-HCC patients in China has been less studied [15]. In view of high HBV endemicity and HCC incidence in China, we performed this study to compare serum HBV DNA level between chronic hepatitis $\mathrm{B}(\mathrm{CHB})$ patients with $\mathrm{HCC}$ and the patients with HBV infection alone to clarify whether the high HBV level is a risk for HCC development.

\section{Results}

Patients' characteristics

In view of the fact that antiviral treatment will influence the HBV DNA level, we excluded the patients who received any antiviral treatment before. After these two group patients were matched for age (fewer than 2 years 
Table 1 Characteristics of HCC and non-HCC patients

\begin{tabular}{llll}
\hline \hline Characteristics & HCC $(\mathbf{n}=\mathbf{9 0})$ & $\begin{array}{l}\text { non-HCC }(\mathbf{n}= \\
\mathbf{9 0})\end{array}$ & $\begin{array}{l}\mathbf{P} \\
\text { value }\end{array}$ \\
\hline Male/Female & $78 / 12$ & $78 / 12$ & \\
Age & $52.53 \pm 10.27$ & $52.53 \pm 10.23$ & 1.000 \\
HBeAg positive & 38 & 12 & $<0.001$ \\
Total Protein (g/L) & $68.2 \pm 6.8$ & $65.5 \pm 8.1$ & 0.017 \\
Albumin $(\mathrm{g} / \mathrm{L})$ & $38.5 \pm 5.0$ & $38.9 \pm 6.4$ & 0.657 \\
Globulin $(\mathrm{g} / \mathrm{L})$ & $29.7 \pm 6.5$ & $26.6 \pm 5.6$ & 0.001 \\
ALT $(\mathrm{IU} / \mathrm{L})$ & $47.50(7.9-926.7)$ & $25.05(7.1-1660.5)$ & $<0.001$ \\
AST $(\mathrm{IU} / \mathrm{L})$ & $48.15(18.7-$ & $26.35(10.4-1071.1)$ & $<0.001$ \\
& $910.9)$ & & \\
Total Bilirubin $(\mu \mathrm{mol} / \mathrm{L})$ & $19.60(3.6-503.9)$ & $16.8(6.7-492.7)$ & 0.021 \\
Direct Bilirubin $(\mu \mathrm{mol} /$ & $7.30(1.7-304.9)$ & $5.15(1.5-353.1)$ & $<0.001$ \\
L) & & & \\
\hline
\end{tabular}

difference) and gender respectively, 90 patients were included in each group. Their average age, serum biochemical values and number of $\mathrm{HBeAg}$ positive patients are expressed in Table 1. Our findings showed the HBeAg positive rate was $42.2 \%(38 / 90)$ in the HCC group while $13.3 \%(12 / 90)$ in the non-HCC group $(P<$ 0.001 ). As shown in Table 2, we found the percentages of patients with abnormal serum alanine aminotransferase (ALT), aspartate aminotransferase (AST), total bilirubin or direct bilirubin of HCC group were higher than those of non-HCC group. This indicates that higher percentage HCC patients are associated with worse liver function.

\section{Comparison of HCC and non-HCC patients' HBV DNA level}

As shown in Table 3, we compared the viral load between $\mathrm{HCC}$ patients and non-HCC patients. The HBV DNA level was higher in HCC group than that in non-HCC group $\left(4.73 \pm 1.71\right.$ vs. $3.90 \pm 2.01 \log _{10}$ IU/ $\mathrm{ml}, P<0.01)$. We further analyzed the viral load of HCC or non-HCC patients stratified by age. The HBV DNA level in HCC group was significantly higher than that of the non-HCC patients in the age range of 50-59 years. This was the same with the age range of below 40 years.

Table 2 The percentage of patients with abnormal serum biochemical parameters

\begin{tabular}{llll}
\hline Parameters & HCC $(\mathbf{n}=\mathbf{9 0})$ & non-HCC $(\mathbf{n}=\mathbf{9 0})$ & P value \\
\hline ALT & $52(57.8 \%)$ & $21(23.3 \%)$ & $<0.001$ \\
AST & $53(58.9 \%)$ & $27(30.0 \%)$ & $<0.001$ \\
Total Bilirubin & $42(46.2 \%)$ & $29(32.2 \%)$ & 0.047 \\
Direct Bilirubin & $48(53.3 \%)$ & $24(26.7 \%)$ & $<0.001$ \\
Total Protein & $16(17.8 \%)$ & $21(23.3 \%)$ & 0.356 \\
Albumin & $23(25.6 \%)$ & $20(22.2 \%)$ & 0.600 \\
Globulin & $18(20.0 \%)$ & $14(15.6 \%)$ & 0.436 \\
\hline
\end{tabular}

Table 3 Comparison of the HCC and non-HCC patients' number and viral load stratified by ages

\begin{tabular}{|c|c|c|c|c|c|c|}
\hline \multirow{2}{*}{$\begin{array}{l}\text { Age } \\
\text { range } \\
\text { (years) }\end{array}$} & \multicolumn{3}{|c|}{$\begin{array}{l}\text { Patients number } \\
\text { (\%) }\end{array}$} & \multicolumn{3}{|c|}{$\begin{array}{c}\text { viral load } \\
\left(\log _{10} \mathrm{IU} / \mathrm{ml} \text {, mean } \pm S D\right)\end{array}$} \\
\hline & $\mathrm{HCC}$ & non-HCC & $\begin{array}{l}P \\
\text { value }\end{array}$ & $\mathrm{HCC}$ & non-HCC & $\begin{array}{l}P \\
\text { value }\end{array}$ \\
\hline All & $\begin{array}{l}90 \\
(100)\end{array}$ & 90 (100) & 1.000 & $4.73 \pm 1.71$ & $3.90 \pm 2.01$ & 0.003 \\
\hline$\geq 60$ & $\begin{array}{l}25 \\
(27.8)\end{array}$ & $22(24.4)$ & 0.611 & $4.48 \pm 1.80$ & $3.56 \pm 1.35$ & 0.056 \\
\hline 50-59 & $\begin{array}{l}29 \\
(32.2)\end{array}$ & 32 (35.6) & 0.637 & $5.20 \pm 1.52$ & $3.98 \pm 2.21$ & 0.015 \\
\hline $40-49$ & $\begin{array}{l}27 \\
(30.0)\end{array}$ & $27(30.0)$ & 1.000 & $4.20 \pm 1.85$ & $4.20 \pm 2.09$ & 0.996 \\
\hline$<40$ & $\begin{array}{l}9 \\
(10.0)\end{array}$ & $9(10.0)$ & 1.000 & $5.51 \pm 0.94$ & $3.61 \pm 2.46$ & 0.046 \\
\hline
\end{tabular}

The odds ratios (ORs) for the association between HCC and various serum HBV DNA level are shown in Table 4. Compared with patients with HBV load of $<3$ $\log _{10} \mathrm{IU} / \mathrm{ml}$, patients with 3 to $<4,4$ to $<5,5$ to $<6$, or $\geq 6 \log _{10} \mathrm{IU} / \mathrm{ml}$ HBV DNA level had the ORs of 1.380 (95\% CI, 0.544-3.499), 3.671 (95\% CI, 1.363-9.886), 5.303 (95\% CI, 1.847-15.277) or 3.030 (95\% CI, 1.1438.036), respectively. These results indicate that patients with serum HBV DNA level of above $10^{4} \mathrm{IU} / \mathrm{ml}$ have a higher risk to develop HCC.

\section{Discussion}

We quantitatively measured serum HBV load in $90 \mathrm{HBV}$ infected patients with HCC and in 90 age- and gendermatched patients with HBV infection alone and found that HCC patients had higher serum HBV DNA level than patients without HCC, especially in the age range of 50-59 years or below 40 years. The data in the present study indicate that the patients with higher HBV level have more risk to develop HCC.

There were a few retrospective studies in which the authors compared HCC and non-HCC patients' HBV DNA level to clarify the role of HBV load in HCC development. Some authors stated the level in HCC patients was higher than that in non-HCC patients $[14,15]$ and $>10^{4}[21]$ or $>10^{5}[13]$ copies $/ \mathrm{ml} \mathrm{HBV}$

Table 4 Odds ratios for the association between HCC and various HBV load

\begin{tabular}{lllll}
\hline $\begin{array}{l}\text { HBV load } \\
(\mathbf{I U} / \mathbf{m l})\end{array}$ & HCC $(\mathbf{n})$ & non-HCC $(\mathbf{n})$ & OR $(\mathbf{9 5} \% \mathrm{Cl})$ & P value \\
\hline$\geq 10^{6}$ & 20 & 15 & $3.030(1.143-8.036)$ & 0.045 \\
\hline $10^{5}-<10^{6}$ & 21 & 9 & $5.303(1.847-15.277)$ & 0.003 \\
\hline $10^{4}-<10^{5}$ & 21 & 13 & $3.671(1.363-9.886)$ & 0.018 \\
\hline $10^{3}-<10^{4}$ & 17 & 28 & $1.380(0.544-3.499)$ & 0.659 \\
\hline$<10^{3}$ & 11 & 25 & 1.000 (reference) & \\
\hline
\end{tabular}


DNA level was supposed to be an independent risk factor of HCC development. As an indicator of active replication of $\mathrm{HBV}$, the higher $\mathrm{HBeAg}$ positive rate is usually associated with an increased risk of HCC [22]. Our findings were similar to these previously reported results. However, in Tsai et al's paper, there existed no significant difference in HCC and non-HCC patients' HBV DNA level [16]. Another study performed in India showed that the HBV DNA load in HCC patients was lower than that of HBV-related chronic liver disease patients [17]. However, in these two studies, the HCC group patients were both obviously older than the nonHCC group patients $(53.7 \pm 12.7$ vs. $32.1 \pm 10.0$ years [16], $53.6 \pm 13.2$ vs. $44.2 \pm 14.7$ years [17]). The evolution and the viral load of HBV infection may be influenced by age at acquisition. In the present study, although it is difficult to determine duration of the infection for each patient, we considered that most patients in our study had been infected with HBV in their infantile or childhood periods as the majority of chronic HBV infection in China is due to the perinatal infections [23]. Thus, the comparable patients' ages in the HCC and non-HCC groups may represent the similar infection durations in the two groups. Since HCC is a long-term outcome of chronic HBV infection and HBV DNA level is usually higher in younger $\mathrm{CHB}$ patients than in older ones [16], the matching of the patients' age is essential in the comparison of HBV DNA level in patients with or without HCC.

Large number chronic HBsAg carriers in Taiwan were followed up for a long period and the prospective data showed an increased risk for cirrhosis and for HCC with increasing level of HBV DNA [24,25]. Several studies have suggested an increased risk of $\mathrm{HCC}$ with high HBV DNA level $\left(>10^{6}\right.$ copies $/ \mathrm{ml}[9], 10^{4}-10^{7}$ copies $/ \mathrm{ml}$ [26] or $>10^{5}$ copies/ml [27]). In our study, the data demonstrated that the patients with higher than $10^{4} \mathrm{IU} /$ ml HBV DNA level had more risk to be diagnosed as HCC, which was similar to the previous prospective reports [25-29]. The commonly used quantitative units of HBV DNA level in papers are $\mathrm{IU} / \mathrm{ml}$ and copies $/ \mathrm{ml}$. In the current WHO HBV standard and consensus, one IU is approximately equivalent to five genome equivalents (copies) [30]. The viral load of $10^{4} \mathrm{IU} / \mathrm{ml}$ identified in this study is approximately equal to $5 \times 10^{4}$ copies/ $\mathrm{ml}$.

\section{Conclusions}

In summary, our findings demonstrated that higher serum HBV load in HCC patients than non-HCC counterparts, especially in the age range of both 50-60 years and below 40 years. Our results suggest that patients with higher than $10^{4} \mathrm{IU} / \mathrm{ml}$ HBV DNA level are associated with more risk to develop HCC.

\section{Methods}

\section{Patients and study design}

A total of 388 CHB patients were admitted to Nanjing Drum Tower Hospital between October 2009 and June 2010. All patients were positive for HBsAg for at least 6 months. One group included $120 \mathrm{CHB}$ patients who were diagnosed with $\mathrm{HCC}$ for the first time. The diagnosis of $\mathrm{HCC}$ was made by pathological findings or a combination of elevated $\alpha$-fetoprotein $(>400 \mathrm{ng} / \mathrm{ml}$ ) and typical appearance on at least two radiological imaging techniques, including ultrasonography, computerized tomography, magnetic resonance imaging, or hepatic angiography with lipiodol. The other group was 268 CHB patients without HCC. The patients with hepatitis $\mathrm{C}$ virus $(\mathrm{HCV})$ or HIV co-infection, primary biliary cirrhosis, autoimmune hepatitis, significant alcohol intake or Wilson's disease were excluded. After we excluded the patients who received any antiviral treatment before, these two group patients were matched for age (fewer than 2 years difference) and gender respectively. As a result, there were 90 patients in each group. All study participants provided informed written consent. All the experiments were approved by the Ethics Committee of Nanjing Drum Tower Hospital, Nanjing University Medical School, in accordance with guidelines of the Nation Health and Medical Research Council of China.

A blood sample was collected from each subject and the serum was separated by centrifugation at room temperature. The serum was stored in a sterile tube at $-20^{\circ}$ $\mathrm{C}$ until use. For HCC patients, serum samples were collected before surgical resection or interventional therapy was performed.

\section{Viral markers assays}

HBsAg and hepatitis B e antigen ( $\mathrm{HBeAg}$ ) were tested by commercial enzyme-linked immunosorbent assays (ELISA) (Huakang Biotechnology, Shenzhen, China). Commercial ELISA kit for anti-HCV was obtained from Huakang (Huakang Biotechnology, Shenzhen, China) and anti-HIV ELISA kit was from Lizhu (Lizhu Biotechnology, Zhuhai, China).

\section{Quantitative assay of HBV DNA}

Serum HBV DNA was quantified with a commercial fluorescent real-time PCR assay (DaAn Gene, Guangzhou, China) [31]. Serum DNA was extracted from 100 $\mu \mathrm{l}$ serum by boiling in DNA extract buffer $(\mathrm{NaOH}$, Tris$\mathrm{HCl}$, TritonX-100, NP40, chelex-100, EDTA) and was dissolved in $20 \mu \mathrm{l}$ DNA solution buffer. Afterwards, $2 \mu \mathrm{l}$ DNA solution was subjected to PCR. The PCR program consisted of $93^{\circ} \mathrm{C}$ for $2 \mathrm{~min}, 10$ cycles of $93^{\circ} \mathrm{C}$ for 45 seconds and $55^{\circ} \mathrm{C}$ for 60 seconds, 30 cycles of $93^{\circ} \mathrm{C}$ for 30 seconds and $55^{\circ} \mathrm{C}$ for 45 seconds. The fluorescence 
signal of the amplicons was detected in every step of $55^{\circ} \mathrm{C}$ for 45 seconds by 7500 real time PCR system (Applied Biosystems, Singapore). The lower detection limit of this assay was $10^{3} \mathrm{IU} / \mathrm{ml}$ with a linear range of up to $10^{7} \mathrm{IU} /$ $\mathrm{ml}$. The known amounts of $10^{3}, 10^{4}, 10^{5}, 10^{6}, 10^{7} \mathrm{IU} / \mathrm{ml}$ HBV DNA were used as a control. Strict precautions were taken to avoid potential contamination.

\section{Statistical analysis}

Serum HBV DNA level was $\log _{10}$-transformed for analysis. Normal distribution data were expressed as mean \pm standard deviation and non-normal distribution data were given as median with range. All the HBV DNA levels below the detection limit $\left(3 \log _{10} \mathrm{IU} / \mathrm{ml}\right)$ were defined as non-measured values and they were arbitrarily estimated as $1.5 \log _{10} \mathrm{IU} / \mathrm{ml}$ in analysis for the reason of estimated continuous distribution of the HBV DNA levels. The differences in liver function and serum DNA level between HCC and non-HCC patients were evaluated by Pearson's Chi-square test, Student's $t$ test and Mann-Whitney $u$ test where appropriate. All estimates were accompanied by a $95 \%$ confidence interval (CI) where appropriate and two-sided $P$ values of fewer than 0.05 were considered statistically significant.

\section{Acknowledgements}

We thank Dr. Decai Yu for collecting some HCC patients' sera. This study was supported by a Special Research Grant (RC2007005) for the Principal Fellow from the Department of Health, Jiangsu Province, China.

\section{Author details}

'Department of Laboratory Medicine, Nanjing Drum Tower Hospital, Nanjing University Medical School, Nanjing, China. ${ }^{2}$ Jiangsu Key Laboratory for Molecular Medicine, Nanjing University Medical School, Nanjing, China.

\section{Authors' contributions}

JYZ collected the samples, performed the experiments, analyzed the data, and drafted the manuscript. $L Z$ and $L L$ assisted in collecting the samples and measuring the HBV DNA. GYG interpreted the data and revised the manuscript. YHZ and JHC designed the study, interpreted the data and critically revised the manuscript. All authors read and approved the final manuscript.

\section{Competing interests}

The authors declare that they have no competing interests.

Received: 29 June 2011 Accepted: 13 January 2012

Published: 13 January 2012

\section{References}

1. Marcellin P: Hepatitis B and hepatitis C in 2009. Liver Int 2009, 29(Suppl 1):1-8.

2. Van Damme P, Zanetti AR, Shouval D, Van Herck K: Strategies for global prevention of hepatitis B virus infection. Adv Exp Med Biol 2010, 659:175-188.

3. Te HS, Jensen DM: Epidemiology of hepatitis B and C viruses: a global overview. Clin Liver Dis 2010, 14:1-21.

4. Chinese Society of Hepatology. Chinese Medical Association and Chinese Society of Infectious Diseases, Chinese Medical Association: Guideline on prevention and treatment of chronic hepatitis B in China (2005). Chin Med J (Engl) 2007, 120:2159-2173.
5. Lim SG, Mohammed R, Yuen MF, Kao JH: Prevention of hepatocellular carcinoma in hepatitis B virus infection. J Gastroenterol Hepatol 2009, 24:1352-1357.

6. Asia-Pacific Working Party on Prevention of Hepatocellular Carcinoma: Prevention of hepatocellular carcinoma in the Asia-Pacific region: consensus statements. J Gastroenterol Hepatol 2010, 25:657-663.

7. Chen CJ, Chen DS: Interaction of hepatitis B virus, chemical carcinogen, and genetic susceptibility: multistage hepatocarcinogenesis with multifactorial etiology. Hepatology 2002, 36:1046-1049.

8. Tsai WL, Chung RT: Viral hepatocarcinogenesis. Oncogene 2010, 29:2309-2324.

9. Ohata K, Hamasaki K, Toriyama K, Ishikawa H, Nakao K, Eguchi K: High viral load is a risk factor for hepatocellular carcinoma in patients with chronic hepatitis B virus infection. J Gastroenterol Hepatol 2004, 19:670-675.

10. Harris RA, Chen G, Lin WY, Shen FM, London WT, Evans AA: Spontaneous clearance of high-titer serum HBV DNA and risk of hepatocellular carcinoma in a Chinese population. Cancer Causes Control 2003, 14:995-1000.

11. Ohkubo K, Kato Y, Ichikawa T, Kajiya Y, Takeda Y, Higashi S, Hamasaki K, Nakao K, Nakata K, Eguchi K: Viral load is a significant prognostic factor for hepatitis B virus-associated hepatocellular carcinoma. Cancer 2002, 94:2663-2668.

12. Chu CJ, Hussain M, Lok AS: Quantitative serum HBV DNA levels during different stages of chronic hepatitis B infection. Hepatology 2002, 36:1408-1415.

13. Liu CJ, Chen BF, Chen PJ, Lai MY, Huang WL, Kao JH, Chen DS: Role of hepatitis $B$ virus precore/core promoter mutations and serum viral load on noncirrhotic hepatocellular carcinoma: a case-control study. J Infect Dis 2006, 194:594-599.

14. Fung J, Yuen MF, Yuen JC, Wong DK, Lai CL: Low serum HBV DNA levels and development of hepatocellular carcinoma in patients with chronic hepatitis B: a case-control study. Aliment Pharmacol Ther 2007, 26:377-382.

15. Xu J, Lin Y, Wang YP, Chen YX, Shi B, Lu J, Xie WF: Hepatitis B virus DNA in patients with hepatitis B-related liver cirrhosis with or without hepatocellular carcinomas: a matched case-control study. J Dig Dis 2009, 10:138-144.

16. Tsai FC, Liu CJ, Chen CL, Chen PJ, Lai MY, Kao JH, Chen DS: Lower serum viral loads in young patients with hepatitis-B-virus-related hepatocellular carcinoma. J Viral Hepat 2007, 14:153-160.

17. Asim M, Malik A, Sarma MP, Polipalli SK, Begum N, Ahmad I, Khan LA, Husain SA, Akhtar N, Husain S, Thayumanavan L, Singla R, Kar P: Hepatitis B virus $\mathrm{BCP}$, Precore/core, $\times$ gene mutations/genotypes and the risk of hepatocellular carcinoma in India. J Med Virol 2010, 82:1115-1125.

18. Zhou $\mathrm{YH}, \mathrm{Wu} \mathrm{C}$, Zhuang $\mathrm{H}$ : Vaccination against hepatitis $\mathrm{B}$ : the Chinese experience. Chin Med J (Engl) 2009, 122:98-102.

19. Liang X, Bi S, Yang W, Wang L, Cui G, Cui F, Zhang Y, Liu J, Gong X Chen $Y$, Wang F, Zheng H, Guo J, Jia Z, Ma J, Wang H, Luo H, Li L, Jin S, Hadler SC, Wang Y: Epidemiological serosurvey of hepatitis B in Chinadeclining HBV prevalence due to hepatitis B vaccination. Vaccine 2009, 27:6550-6557.

20. Yuen MF, Hou JL, Chutaputti A: Hepatocellular carcinoma in the Asia pacific region. J Gastroenterol Hepatol 2009, 24:346-353.

21. Yuen MF, Tanaka Y, Shinkai N, Poon RT, But DY, Fong DY, Fung J, Wong DK, Yuen JC, Mizokami M, Lai CL: Risk for hepatocellular carcinoma with respect to hepatitis $B$ virus genotypes $B / C$, specific mutations of enhancer II/core promoter/precore regions and HBV DNA levels. Gut 2008, 57:98-102

22. Yang HI, Lu SN, Liaw YF, You SL, Sun CA, Wang LY, Hsiao CK, Chen PJ, Chen DS, Chen CJ: Hepatitis B e antigen and the risk of hepatocellular carcinoma. N Engl J Med 2002, 347:168-174

23. Yao GB: Importance of perinatal versus horizontal transmission of hepatitis B virus infection in China. Gut 1996, 38(Suppl 2):S39-S42.

24. Yu MW, Yeh SH, Chen PJ, Liaw YF, Lin CL, Liu CJ, Shih WL, Kao JH, Chen DS, Chen CJ: Hepatitis B virus genotype and DNA level and hepatocellular carcinoma: a prospective study in men. J Natl Cancer Inst 2005, 97:265-272.

25. Chen CJ, Yang HI, Su J, Jen CL, You SL, Lu SN, Huang GT, lloeje UH: Risk of hepatocellular carcinoma across a biological gradient of serum hepatitis B virus DNA level. JAMA 2006, 295:65-73.

26. Liu TT, Fang $Y$, Xiong $H$, Chen TY, Ni ZP, Luo JF, Zhao NQ, Shen XZ: A casecontrol study of the relationship between hepatitis $B$ virus DNA level 
and risk of hepatocellular carcinoma in Qidong, China. World J Gastroenterol 2008, 14:3059-3063.

27. Ito K, Arai M, Imazeki F, Yonemitsu Y, Bekku D, Kanda T, Fujiwara K, Fukai K, Sato K, Itoga S, Nomura F, Yokosuka O: Risk of hepatocellular carcinoma in patients with chronic hepatitis B virus infection. Scand I Gastroenterol 2010, 45:243-249.

28. Chan HL, Wong WW, Wong GL, Chim AM, Lai LH, Sung JJ: Evaluation of impact of serial hepatitis $B$ virus DNA levels on development of hepatocellular carcinoma. J Clin Microbiol 2009, 47:1830-1836.

29. Chen G, Lin W, Shen F, lloeje UH, London WT, Evans AA: Past HBV viral load as predictor of mortality and morbidity from HCC and chronic liver disease in a prospective study. Am J Gastroenterol 2006, 101:1797-1803.

30. Bowden DS, Thompson AJ: New developments in HBV molecular diagnostics and quantitative serology. Hepatol Int 2008, 2:3-11.

31. Liu BM, Li T, Xu J, Li XG, Dong JP, Yan P, Yang JX, Yan L, Gao ZY, Li WP, Sun XW, Wang YH, Jiao XJ, Hou CS, Zhuang H: Characterization of potential antiviral resistance mutations in hepatitis $B$ virus reverse transcriptase sequences in treatment-naive Chinese patients. Antiviral Res 2010, 85:512-519.

doi:10.1186/1743-422X-9-16

Cite this article as: Zhou et al: High hepatitis B virus load is associated with hepatocellular carcinomas development in Chinese chronic hepatitis B patients: a case control study. Virology Journal 2012 9:16.

\section{Submit your next manuscript to BioMed Central} and take full advantage of:

- Convenient online submission

- Thorough peer review

- No space constraints or color figure charges

- Immediate publication on acceptance

- Inclusion in PubMed, CAS, Scopus and Google Scholar

- Research which is freely available for redistribution

Submit your manuscript at www.biomedcentral.com/submit
C Biomed Central 